\title{
EFFECTS OF PHOSPHORUS ON POLYPHOSPHATE ACCUMULATION BY CUNNINGHAMELLA ELEGANS
}

\author{
Marcos Antonio Barbosa de Lima ${ }^{1,2,3}$; Aline Elesbão do Nascimento ${ }^{1,2}$; Wanderley de Souza ${ }^{4}$; \\ Kazutaka Fukushima ${ }^{5}$; Galba Maria de Campos-Takaki ${ }^{1,2,3 *}$
}

\begin{abstract}
${ }^{1}$ Núcleo de Pesquisas em Ciências Ambientais; Departamentos de Biologia e Química, Universidade Católica de Pernambuco, Recife, PE, Brasil. ${ }^{2}$ Laboratório de Imunopatologia Keizo Asami, Microscopia Eletrônica, Universidade Federal de Pernambuco, Recife, PE, Brasil. ${ }^{3}$ Centro de Ciências Biológicas, Departamento de Micologia, Mestrado em Biologia de Fungos, Universidade Federal de Pernambuco, Recife, PE, Brasil. ${ }^{4}$ Instituto de Biofísica Carlos Chagas Filho, Laboratório de Ultraestrutura Celular, Universidade Federal do Rio de Janeiro, Rio de Janeiro, RJ, Brasil. ${ }^{5}$ Research Center for Pathogenic Fungi and Microbial Toxicosis, Chiba University, Chiba, Japan.
\end{abstract}

Submitted: February 02, 2003; Returned to Authors for corrections: April, 29, 2003; Approved: July 08, 2003

\begin{abstract}
The content of inorganic polyphosphate and the polymeric degree of these compounds were evaluated during the growth of Cunninghamella elegans in medium containing varying orthophosphate ( $\mathrm{Pi}$ ) concentrations. For this purpose, a combination of chemical methods for polyphosphate extraction and ultrastructural cytochemistry were used. The orthophosphate and glucose consumption was also determined during the fungal cultivation. At Pi concentrations of 0.5, 2.5 and $0.0 \mathrm{~g} / \mathrm{L}$, the maximum amounts of biomass were 3.18, 3.29 and $0.24 \mathrm{~g} / \mathrm{L}$, respectively. During growth the cells accumulated Pi from the medium. At three days of growth the biomass consumed up to 100 and $95 \%$ of Pi from the media at initial concentrations of 0.5 and $2.5 \mathrm{~g} / \mathrm{L}$, respectively. Polyphosphate was observed at different Pi concentrations in medium and at different stages of growth. Polyphosphate was assayed by the content of labile phosphorus in water, acid-insoluble and alkali-soluble fractions. The content of fractions changed according to phosphorus concentration in the media and growth phase. During growth on all three media used, the cytochecmical behavior of polyphosphate changed considerably. The results obtained in this study reveal a potential of Cunninghamella elegans in the polyphosphate accumulation, and suggest a future application in the biotechnological processes.
\end{abstract}

Key words: polyphosphate, accumulation, ultrastructural cytochemistry, Cunninghamella elegans, ortophosfate.

\section{INTRODUCTION}

Phosphorus is an essential element for all cells. Besides being an important constituent of organic molecules, phosphorus can be present not only as orthophosphate (Pi) but also as condensed inorganic phosphates $(4,5,22,23,24,28,31,32)$.

Polyphosphates (polyP), polymers of phosphate linked by highly energetic phosphoanhydride bonds, have been detected in all organisms studied including bacteria, yeasts, fungi, plants and animals $(22,24,28,31,32)$. The data in the literature reveal substancial changes in the functions of polyP and their metabolism in the process of evolution from prokaryotes to lower eukaryotes and finally, to highly organized living beings $(31,32,37,38,74)$. Several roles have been proposed for polyP in microbial metabolism, including as a reservoir of energy and phosphate, chelator for metals, a substrate for the phosphorilation of glucose, a capsule material, a channeling agent in the phenomenon of bacterial transformation and pathogenesis $(34,54,55,56,57)$. However, the exact physiological function of polyP remains uncertain $(32,37,38,74)$.

*Corresponding author. Mailing address: Universidade Católica de Pernambuco. Rua Nunes Machado, 42, Bloco J. Boa Vista. 50050-900, Recife, PE. Fax: (+5581) 3216-4043. E-mail: takaki@unicap.br 
The energy state of the cell may be a key factor influencing the synthesis of polyP from ATP or regeneration of polyP. There is evidence that polyP accumulates during energy-rich growth conditions and is degraded during energy-poor conditions $(31,38,49,61,65,72)$. In general physiological terms it has been usual to consider polyP in terms of their solubility. The extent of solubility depends on physiological conditions of the cells. It is known that various polyP fractions are localized in separate cell compartments. The location of polyP fractions may represent differences in their functions $(7,23,57,61,65,69,70,72,74)$.

Formation of polyP by microorganisms during sewage disposal is an important means of removing excess phosphate. The ability to acumulate polyP as a response of physiological adaptation during growth and development has been observed in some microorganisms. The search for new microorganisms, which can accumulate phosphate from environment is in progress. The biotechnological concerning mechanisms promoting oversynthesis of polyP by microorganisms is of economic significance $(42,44,47,72)$.

Zygomycetes are of great interest to the industrial and economic areas due to its habilities involved in process of biodegradation and biodeterioration, and in secretion of secondary metabolites such as enzymes, organic acids, pigments, alcohols, steroids and vitamins $(1,13,46,48,64,73)$. Among the Zygomycetes, Cunninghamella genus is one of the most common members of the order Mucorales, frequently found in soil, grains and other organic substrates. Includes species with particularly medical, industrial and environmental importance, which are able to responde to a inumerous environmental alterations such as gas concentrations, physical and chemical changes $(1,3,46,62,68)$. Cunninghamella elegans has the ability to metabolize xenobiotics, including polycyclic aromatic hydrocarbons and pharmaceutical drugs and has been widely used in bioremediation and microbial models of mammalian studies $(17,40,50,51,52,59,66,75,76)$.

In this paper we report the effects of phosphate concentration in the culture medium on growth, phosphate accumulation, the content of some polyP fractions and the polyP ultrastructural cytochemistry in the cells of C. elegans.

\section{MATERIALS AND METHODS}

\section{Microorganism and culture conditions}

Cunninghamella elegans (IFM 46109) was kindly supplied by the Culture Collection of the Research Center for Pathogenic Fungi and Microbial Toxicosis, Chiba University- Japan. The culture was mantained on Difco PDA (Potato Dextrose Agar) slants, incubated at $26^{\circ} \mathrm{C}$. The PDA medium was used for large scale spore production, during 5 days at $28^{\circ} \mathrm{C}$. A total of $10^{8}$ spores $/ \mathrm{mL}$ were collected and transferred to Erlenmeyer flasks containing $40 \mathrm{ml}$ of SMM (Synthetic Medium for Mucoralean described by Hesseltine and Anderson, 1957 (21)) modified by the use of different monobasic potassium phosphate concentrations of $0.5 \mathrm{~g} / \mathrm{L}$ (SMM1), $2.5 \mathrm{~g} / \mathrm{L}$ (SMM2), and $0.0 \mathrm{~g} /$ L (SMM3). The cultures were incubated during 12 days, at $28^{\circ}$, at $250 \mathrm{hz}$. All samples were prepared in five replicas.

\section{Growth curves}

Samples collected at 3, 6, 9, and 12 days of culture were submitted to liophylization and mantained in a vacuum dissecator until constant weight. The final value corresponded to arithmetic media of five replicas of each sample.

\section{Analytical procedure}

All analytical procedures were performed by using samples of culture supernatant collected at 3, 6,9 and 12 days of cultive. The final value corresponded to arithmetic media of five replicas of each sample. The $\mathrm{pH}$ curves were obtained by potenciometry. The phosphate consumption was evaluated by using the spectrophotometric assay, based on the Biosystems kit. A standard curve was produced by using a potassium phosphate solution $(0.5$ to $5.0 \mathrm{~g} / \mathrm{L})$. The reading were made in a spectrophotometer Spectronic Genesys 2, at ultraviolete spectrum. The glucose consumption was determined by the use of enzymatic colorimetric method, Celm Kit. A standard curve was elaborated by using a glucose solution $(0.5$ to $5.0 \mathrm{~g} /$ L) (20).

\section{Polyphosphate determination}

The total cellular polyP was extracted and determined by the method described by McGrath and Quinn (42). Cells were harvested at 3, 6, 9 and 12 days of culture, washed twice in 1.5 $\mathrm{M} \mathrm{NaCl}$ containing $0.01 \mathrm{M}$ EDTA and $1 \mathrm{mM} \mathrm{NaF}$ (wash buffer). The cell pellet was resuspended in $1.5 \mathrm{~mL}$ of wash buffer and sonicated on ice, for 24 min period with 2 min intervals at 16 $\mathrm{KHz}$. The resulting homogenate was centrifuged at $12,000 \mathrm{~g}$ for $5 \mathrm{~min}$ to remove cell debris. To determine total intracellular polyP, $100 \mu \mathrm{L}$ of concentrated $\mathrm{HCl}$ was added to $0.5 \mathrm{~mL}$ of cell extract and heated at $100^{\circ} \mathrm{C}$ for $45 \mathrm{~min}$, the phosphate liberated was assayed by the spectrophotometric method made in a Spectronic Genesys 2, at ultraviolete spectrum. The polyP concentrations were expressed in gram of phosphate per gram of biomass as means of five replicas. An unhydrolized sample was used as a control to determine the background level of polyP.

\section{Extraction of Polyphosphate Fractions}

A sequential polyP extraction was performed by using the methods described by Dietrich (12) and Smirnov (65), modified in samples collected at 6 and 12 days of culture. The biomass was extracted initially in $5 \mathrm{~mL}$ of deionized water at $0^{\circ} \mathrm{C}$ for 10 $\min$ and sonicated on ice, for $8 \min$ period at $16 \mathrm{KHz}$. The resulting homogenate was centrifuged at $12,000 \mathrm{~g}$ for $5 \mathrm{~min}$ to remove cell debris. The supernatant was the water-soluble fraction of polyP. The precipitate was then extracted by $0.05 \mathrm{~N}$ 
$\mathrm{NaOH}(\mathrm{pH} 12)$ at $0^{\circ} \mathrm{C}$ for $30 \mathrm{~min}$ and alkali-soluble fraction of polyP was then obtained by centrifugation at $12.000 \mathrm{~g}$ for $5 \mathrm{~min}$. The remaining precipitate was treated with $0.5 \mathrm{~N} \mathrm{HClO}_{4}$ for 30 min at $90^{\circ} \mathrm{C}$ and acid-insoluble fraction of polyP was obtained by centrifugation at $12,000 \mathrm{~g}$ for $5 \mathrm{~min}$. The orthophosphate and labile phosphorus content were determined in the watersoluble, alkali-soluble and acid-insoluble fractions. The amount of labile phosphorus was evaluated by the difference in orthophosphate $(\mathrm{Pi})$ content prior and after hydrolysis in $1 \mathrm{~N}$ $\mathrm{HCl}$ at $100^{\circ} \mathrm{C}$ for $10 \mathrm{~min}$.

\section{Electron microscopy - Polyphosphate cytochemistry}

The cytochemical detection of polyP was performed according to De Souza (11) and Ebbel et al. (14). C. elegans samples, grown in liquid SMM1, SMM2 and SMM3, were collected at interval of 3, 6, 9, and 12 days of culture. Samples were washed twice in PBS, pH 7.2 for 10 min, fixed in 2,5\% glutaraldehyde, in $0.1 \mathrm{M}$ cacodylate buffer $\mathrm{pH} 6.5$ during $1 \mathrm{~h}$ at $4^{\circ} \mathrm{C}$ and washed in distilled water. Samples were incubated in $2 \%$ lead nitrate solution, $\mathrm{pH} 3.4$ during $4 \mathrm{~h}$ at $4^{\circ} \mathrm{C}$, and in $1 \%$ ammonium sulphite, during $30 \mathrm{~min}$ at $4^{\circ} \mathrm{C}$. After this period, samples were washed in distilled water, post-fixed in $1.0 \%$ osmium tetroxide, for $1 \mathrm{~h}$ at $4^{\circ} \mathrm{C}$. Post-fixation was followed by washing in distilled water. Samples were dehydrated in acetone and embedded in Epon. Thin sections were obtained in a REICHERT JUNG ultramicrotome, collected on copper grids. Eletronmicrographs were obtained in a JEOL CX 100 Transmission Electron Microscope, operating at $80 \mathrm{KV}$. Control samples were incubated in trichloroacetic acid after the fixation during $6 \mathrm{~h}$ at $4^{\circ} \mathrm{C}$. After this period, samples were treated as cited before.

\section{RESULTS}

Figs. 1, 2 and 3 exhibit C. elegans growth curves, for $\mathrm{pH}$ (A), phosphate (B) and glucose (C) consumption in the SMM media with differents Pi concentrations $(0.5 \mathrm{~g} / \mathrm{L}, 2.5 \mathrm{~g} / \mathrm{L}$ and $0.0 \mathrm{~g} / \mathrm{L}$, respectively).

When the phosphate concentration in the medium was 0.5 $\mathrm{g} / \mathrm{L}$ (Figure 1A-C), the culture presented a logarithimic growth about 3 days, but still growing until the end of experiment, when the maximum yield of biomass was $3.18 \mathrm{~g} / \mathrm{L}$. According to Fig. 1B the phosphate consumption corresponded to $100 \%$ during the begin of the growth (day 3 ). A consumption of $55 \%$ of glucose was observed during growth in this medium correpondend to the maximum yield of biomass (Fig. 1C).

At phosphate concentration of $2.5 \mathrm{~g} / \mathrm{L}$ an increase of biomass was observed during 12 days of growth. The yield of biomass was $3.29 \mathrm{~g} / \mathrm{L}$. The phosphate consumption during 3 days of growth was $95 \%$ (Fig. 2B). The glucose content in the culture medium decrease during cellular growth, and by the end of cultivation $56 \%$ was used by cells (Fig. 2C).

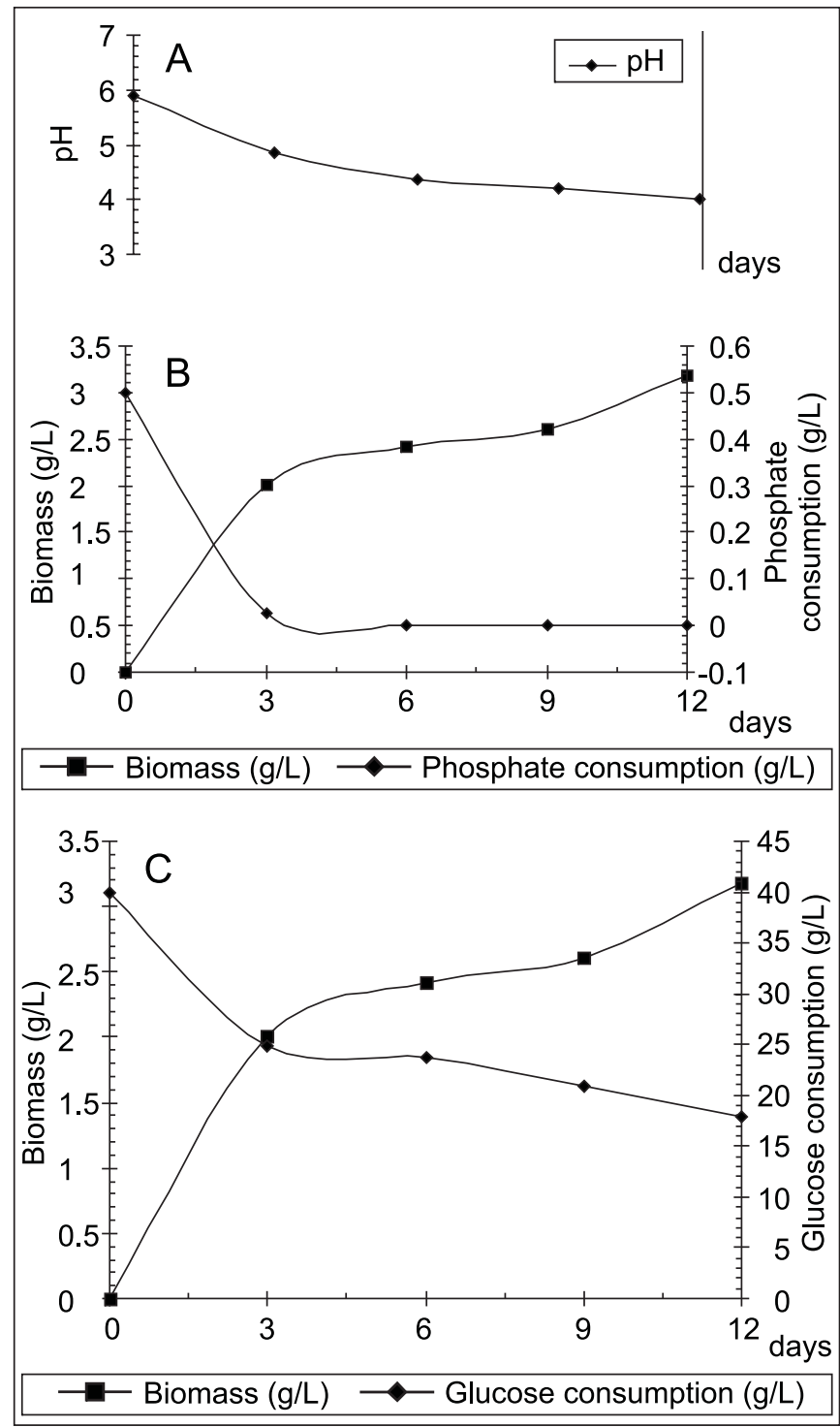

Figure 1. Profile of Cunninghamella elegans grown in SMM1 medium. pH (A), biomass and orthophosphate consumption (B) and biomass and glucose consumption (C).

During the growth in SMM3, cells exhibit the lowest yield of biomass, $0.24 \mathrm{~g} / \mathrm{L}$ by the end of cultivation. The glucose consumption corresponded to $30 \%$ (Fig. 3A-B).

PolyP accumulation was evaluated in cells of $C$. elegans cultivated in media with different phosphate concentrations, $0.5 \mathrm{~g} / \mathrm{L}$ and $2.5 \mathrm{~g} / \mathrm{L}$, and in different phases of cellular growth (Figs. 4 and 5)

When $C$. elegans was cultived in $0.5 \mathrm{~g} / \mathrm{L}$ the total polyP in the biomass corresponded to $0.062 \mathrm{~g} / \mathrm{L}$ at the third day of cultive and decreased by the end of cultivation reaching $0.029 \mathrm{~g} / \mathrm{L}$ (Fig. 4A). A relationship between phosphate consumption and glucose consumption during growth is showed (Fig. 4B). 


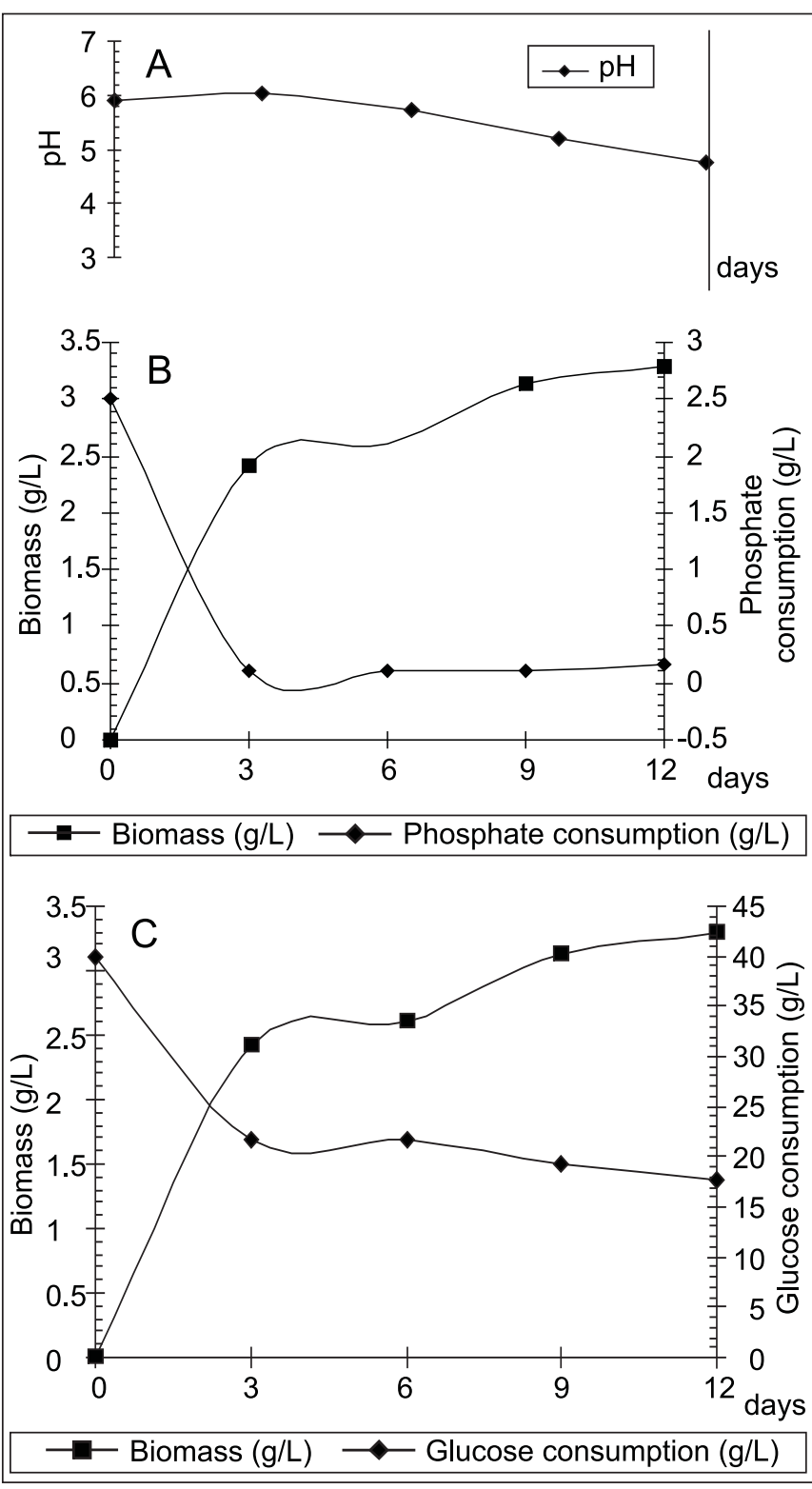

Figure 2. Profile of Cunninghamella elegans grown in SMM2 medium. pH (A), biomass and orthophosphate consumption (B) and biomass and glucose consumption (C).

On the other hand, when $C$. elegans was cultivated in the SMM 2 media $(2.5 \mathrm{~g} / \mathrm{L}$ of $\mathrm{Pi})$ the maximum content was observed by the sixth day of growth with $0.1 \mathrm{~g} / \mathrm{L}$ and by the end of cultivation the content reduced to $0.068 \mathrm{~g} / \mathrm{L}$ (Fig. 5A). By the exponential phase of growth, the content of biomass polyP reached the highest values at initial concentrations of both 0.5 and $2.5 \mathrm{~g} / \mathrm{L}$ of phosphate in the medium. A relationship between phosphate consumption and glucose consumption is presented (Fig. 5B).

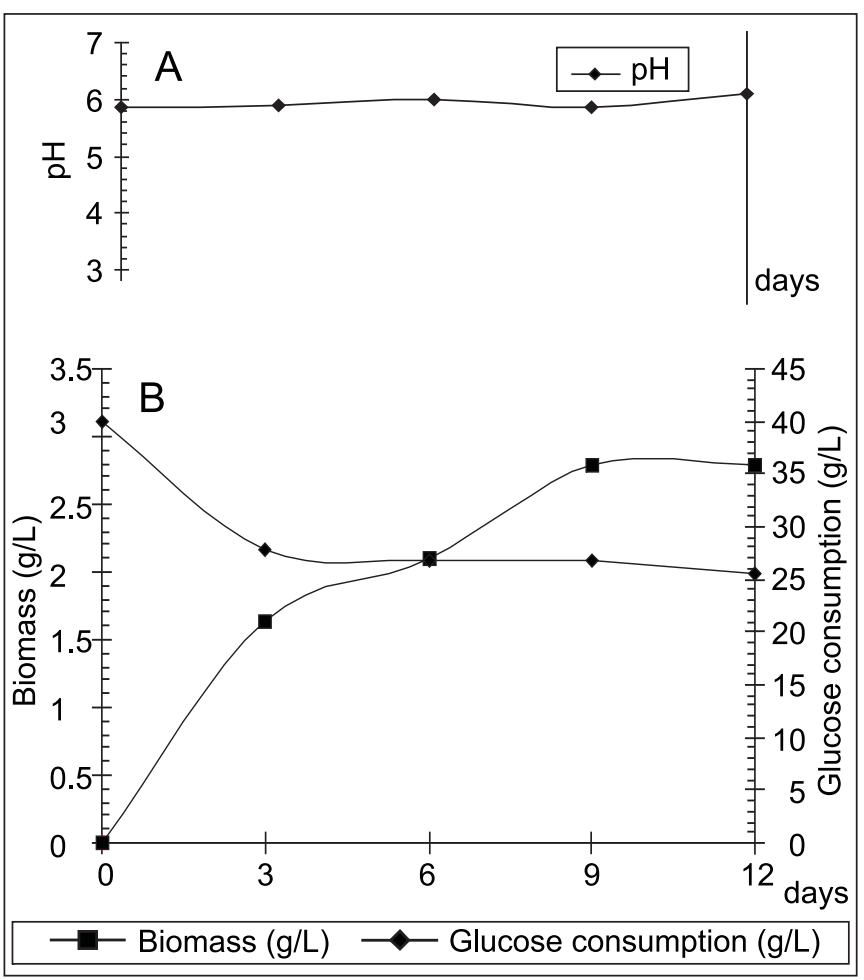

Figure 3. Profile of Cunninghamella elegans grown in SMM3 medium. $\mathrm{pH}$ (A), biomass and glucose consumption (B).

The content of polyP of the water-soluble fraction depended on the concentration of phosphate in the medium and the stage of growth. During growth in the two media used, the content of polyP of this fraction changed. At the Pi concentration of $0.5 \mathrm{~g} / \mathrm{L}$, the content was the highest by the stationary stage and the lowest at the logarithimic growth phase (Fig. 6A). When the concentration of $\mathrm{Pi}$ was $2.5 \mathrm{~g} / \mathrm{L}$, the content was the highest by the logarithmic stage of growth and then decreased (Fig. 6B).

The content of polyP in the acid-insoluble fractions varied according to the $\mathrm{Pi}$ initial concentrations in the culture media and stage of growth. At low initial Pi concentration, the content was high in logarithmic growing cells and decreased during the final stages of growth (Fig. 6A). At Pi concentrations of $2.5 \mathrm{~g} / \mathrm{L}$, the polyP content of this fraction enhanced by the final stages of growth (Fig. 6B).

As for as ultrastructural cytochemistry for polyP of $C$. elegans are concerned, the analysis of micrographs permited to observe differences in the cell fine structure according to stage of growth and initial Pi concentration in the culture medium, related to cytoplasm homogeneity and cell wall thickness. $C$. elegans grown in media containing different Pi concentrations presented differences in the labeling pattern of product of reaction of the cytochemical for polyP (Figs. 7, 8 and 9). 


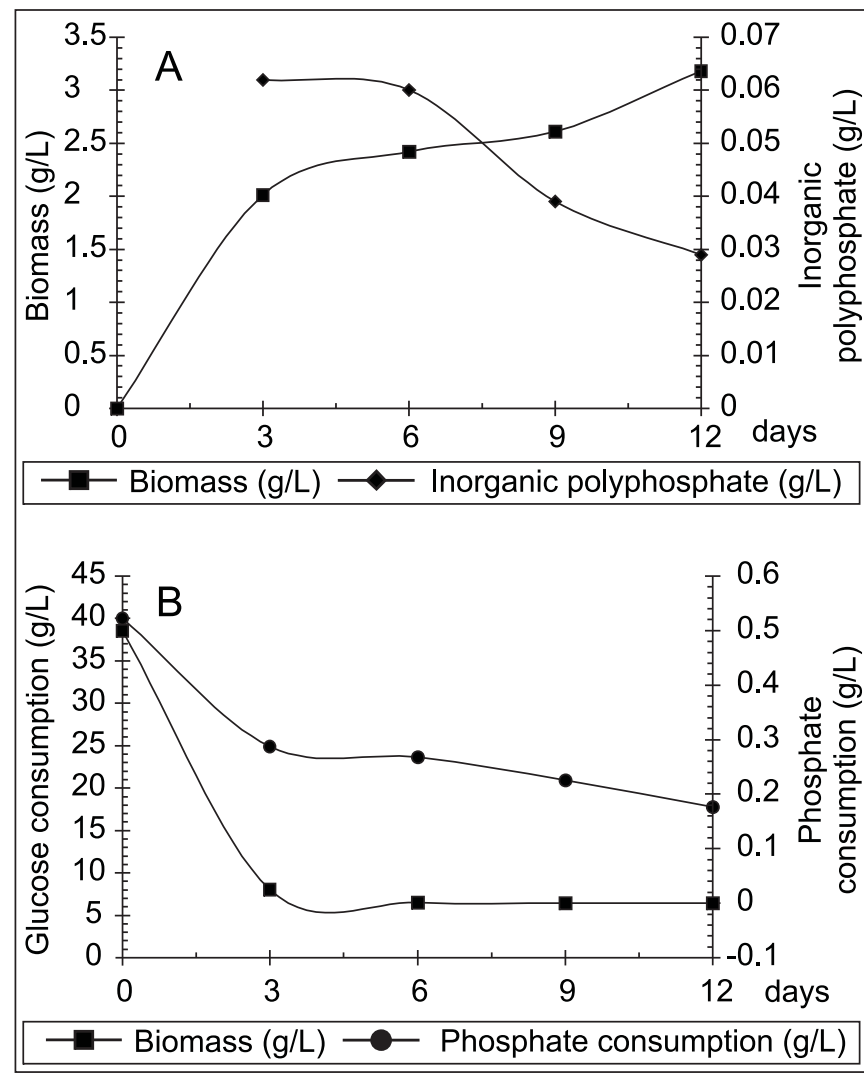

Figure 4. Accumulation of polyphosphate by Cunninghamella elegans grown in SMM1 medium (A), related to orthophosphate and glucose consumption (B).

The intensity, arrangement, distribution and location of cytochemical labeling deposition changed according to $\mathrm{Pi}$ concentration in the culture medium. When the initial $\mathrm{Pi}$ concentration was $0.5 \mathrm{~g} / \mathrm{L}$ (Fig. 7A-F), the intensity of reaction products was lower than that observed in cells grown in $\mathrm{Pi}$ at $2.5 \mathrm{~g} / \mathrm{L}$ (Fig. 8A-F), but higher compared to cells grown in the absence of phosphate (Fig. 9A-F).

The products of reaction were observed in the form of eletrondense bodies of different sizes and agreggates in cell wall, cell membrane, cytoplasm and in intracellular membranous structures. The intensity of labeling decrease by the end of cultivation.

\section{DISCUSSION}

Phosphorus is an integral part of the cellular metabolism since it is indispensible for energy supply and for DNA, RNA and phospholipid biosynthesis. Under natural conditions, the amount of phosphorus available for biosynthetic purposes will depend not only on the total amount of phosphate in the environment, but also on its solubility, which is dictated by

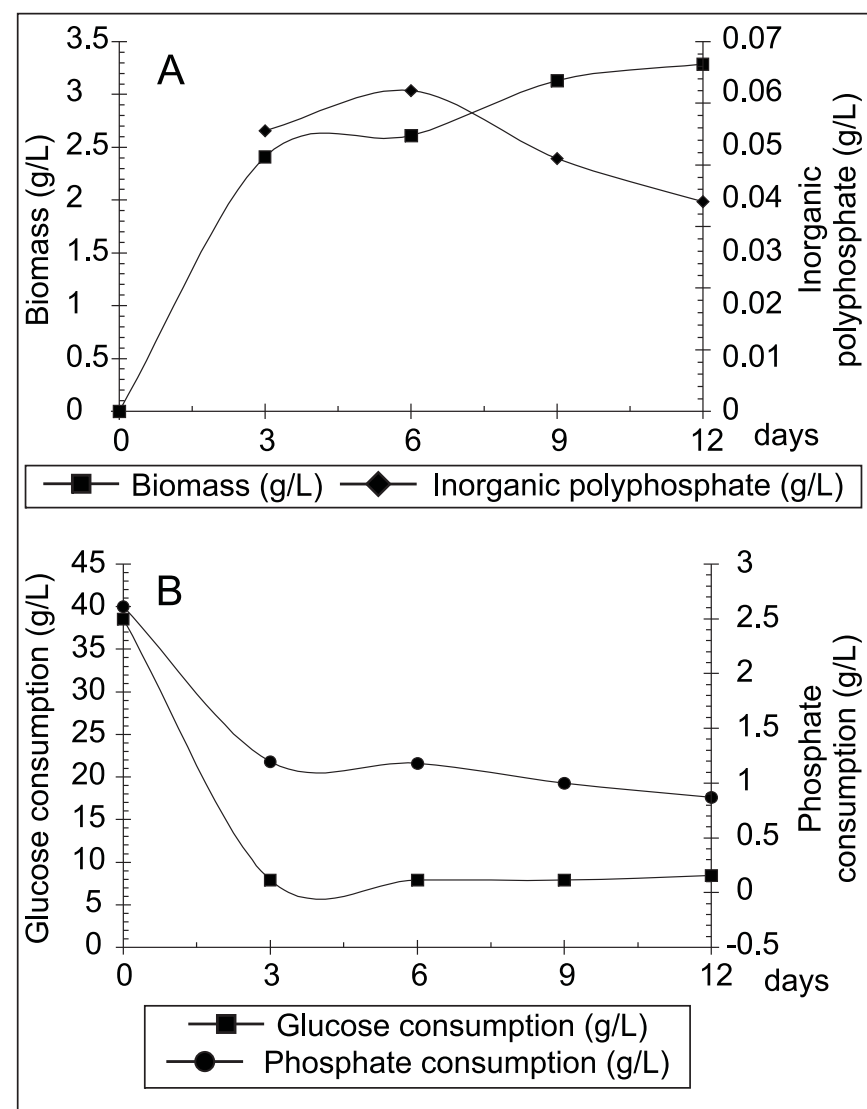

Figure 5. Accumulation of polyphosphate by Cunninghamella elegans grown in SMM2 medium (A), related to orthophosphate and glucose consumption (B).

others chemical and physical factors of the environment $(4,5,18,24,33,49)$.

Microorganisms must accumulate phosphates and phosphorus-containing nutrients from the environment under adverse conditions. PolyP accumulation has been demonstrated for a wide variety of microorganisms, although the conditions favouring this accumulation differ markedly $(29,30,35,36,44,58,74)$. In general polyP concentration is low during the exponential growth but may increase either, when the stationary phase begins or when growth is arrested due to nutrient imbalance $(24,42,58,71)$.

The study of polyP accumulation by microorganisms growing under differential conditions is important to understand the mechanism of biosynthesis, functions, accumulation and further development of removing processes of environmental pollulants $(33,44,65,71)$.

In this paper we describe the effects of orthophosphate content in the medium on the accumulations and the qualitative and quantitative changes of polyP during growth of C. elegans. The results demonstrated a significative variation in the biomass yield of cultures grown in medium containing different 


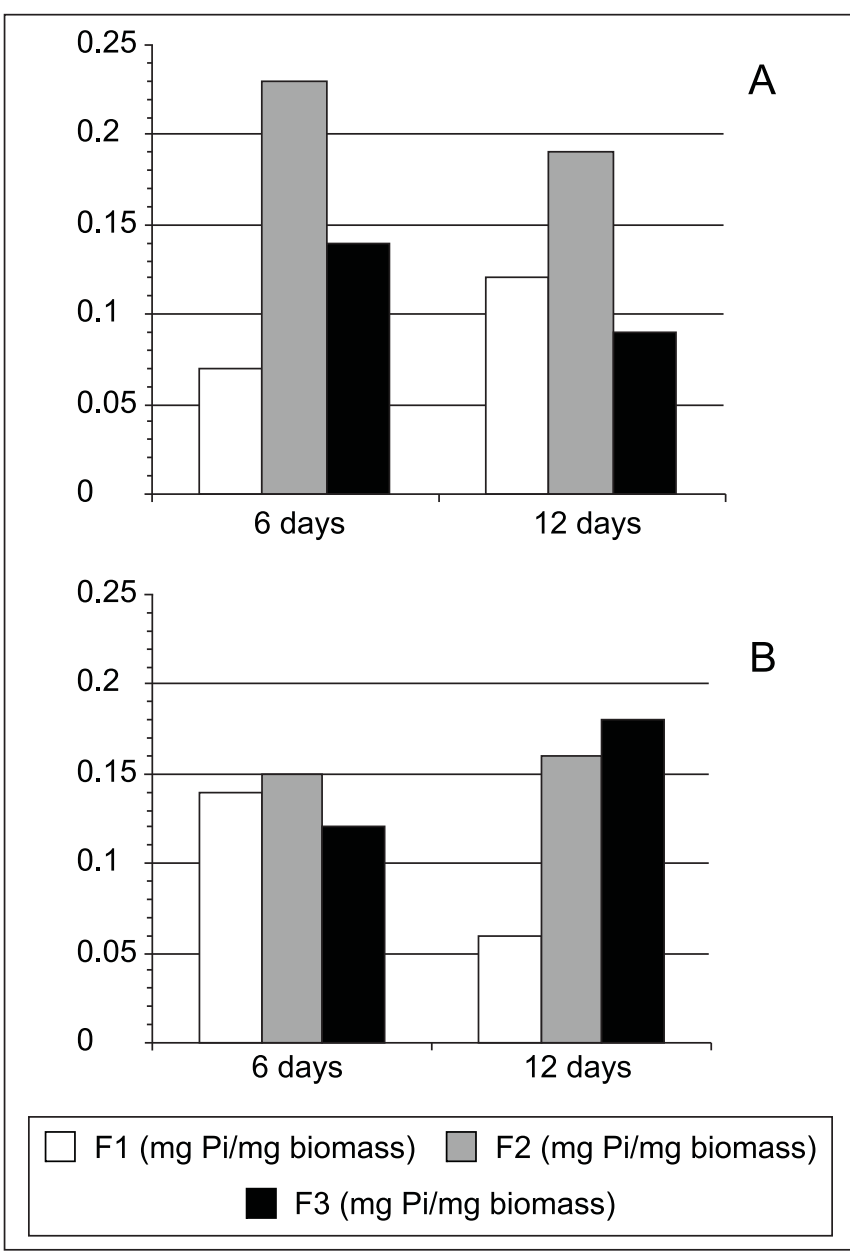

Figure 6. Polyphosphate fractions of Cunninghamella elegans mycelia grown in SMM1 medium (A) and SMM2 medium (B). F1-Water-soluble fraction, F2- Alkali-soluble fraction, F3- Acidinsoluble fraction.

phosphate concentrations, an increase of $4 \%$ was observed in the biomass yield by using a $2.5 \mathrm{~g} / \mathrm{L}$ of orthophosphate. The absence of orthophosphate in the medium induced a decrease of $92 \%$ in the biomass yield of C. elegans.

The rate of phosphate consumption by $C$. elegans depended on the stage of growth and the amount of phosphate in culture medium. The rate of uptake reached its maximum by the third day of growth in both media containing 0.5 and $2.5 \mathrm{~g} / \mathrm{L}$ of orthophosphate. A significant relationship among polyP content, phosphate consumption and glucose utilization was observed. The participation of inorganic phosphate in the biomass production is related, probably, to its dependence on the glycolysis.

Some studies revealed that addition of phosphate to cells previously subjected to phosphate starvation also induces rapid accumulation of PolyP; a phenomenon known as polyP overplus

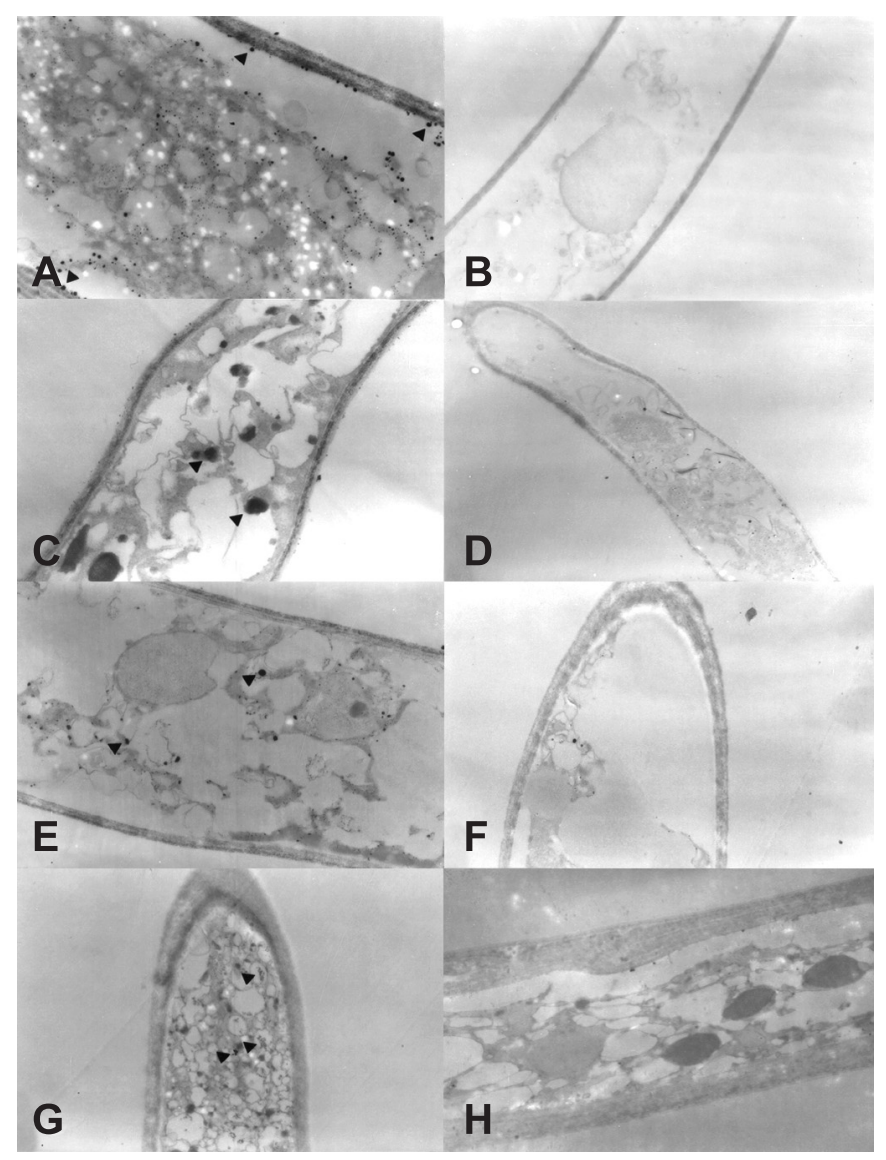

Figura 7. Cunninghamella elegans grown in SMM1 medium. Polyphosphate cytochemistry. A- 3 days 20000X; C- 6 days 27000X; E- 9 days 20000X; G-12 days 14000X. Reaction products ( ). B, D, F and H - control samples.

$(42,65)$. PolyP are present in large amounts in cells growing on a complete medium with high orthophosphate content. Conversely, when phosphate-rich cells are grown in a medium lacking phosphate, polyP disappears $(42,65)$.

Metabolic changes related to $\mathrm{pH}$ of the culture medium, phosphorus content and polyP chain size in cells on stationary and logarithmic growth phases were demonstrated in different microorganisms, including fungi $(4,5,18,24,42,65,72)$.

Changes in the phosphorus content that take place during the growth phases and revealed that Zygomycetes, such as Absidia cylindrospora, Gongronella butleri and Mucor javanicus cells in exponential growth phase exhibited the highest inorganic phosphorus content compared to cells in other growth phases, indicating the necessity to evolve metabolic activities in this period of cellular growth. The inorganic phosphorus content decrease during the cellular growth cycle suggesting its utilization for molecular synthesis of cellular compounds $(10,13,63)$. 


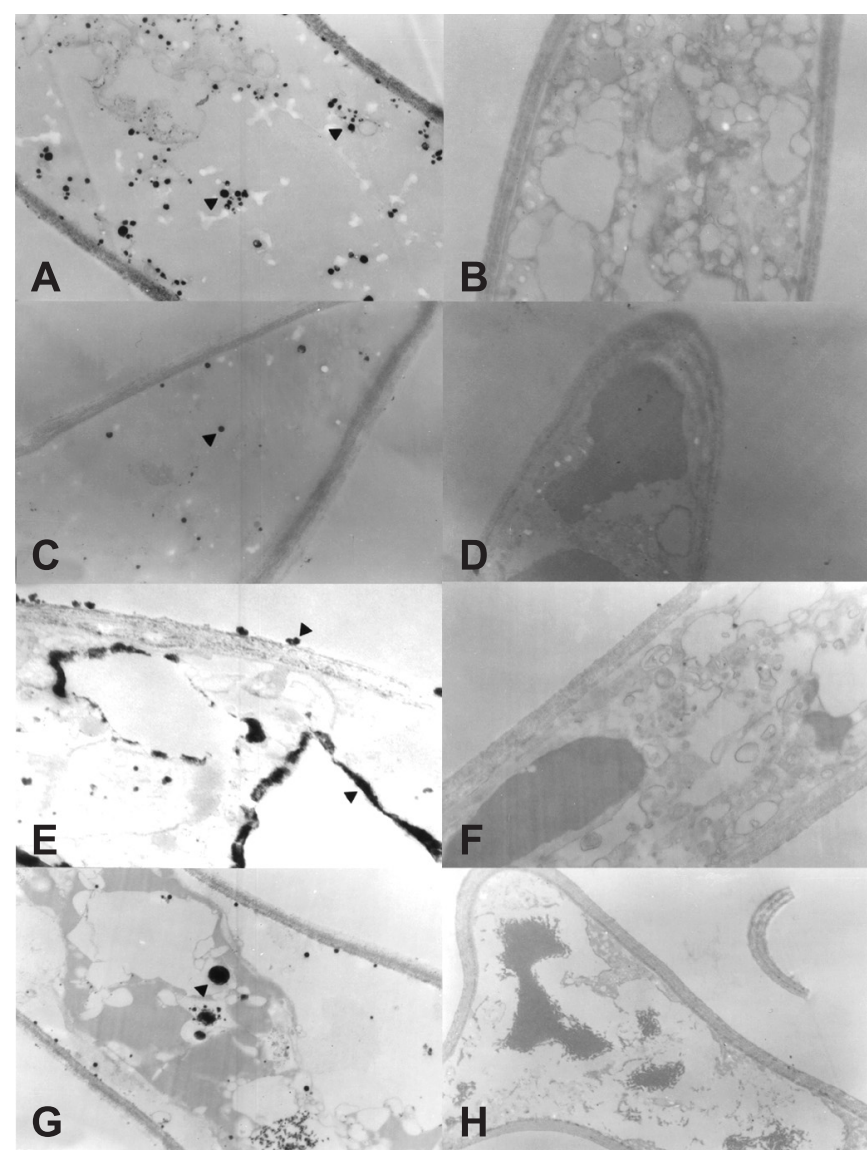

Figura 8. Cunninghamella elegans grown in SMM2 medium. Polyphosphate cytochemistry. A- 3 days 20000X; C - 6 days 27000X; E- 9 days 20000X; G-12 days 14000X. Reaction products ( ). B, D, F and $\mathrm{H}-$ control samples.

The highest mycelial polyP amount was obtained when cells were grown in media containing high phosphate concentrations, and during exponential growth phase. A comparation between the media used in this work revealed an increase of 45, 73, 115 and $142 \%$, at 3, 6, 9 and 12 days of culture in Pi concentrations of 0.5 and $2.5 \mathrm{~g} / \mathrm{L}$, respectively.

Changes in the content of cellular polyP have been detected in fungi and the results suggest that orthophosphate concentration and the type of molecule used as phosphate source induced alterations in the amount of polyP. Potassium Phosphate and Magnesium Phosphate are described as the most important $(42,65,72)$.

In more recent studies it has become clear that specific fractions of polyP represent various pools of polyP, differing their localization in the cell. The synthesis of polyP is related to the metabolism of specific cellular compartments $(32,34,36,37,42,65,72)$

Localization of polyP depends on the chain length. The low molecular weight acid-soluble polyP are located in the volutin

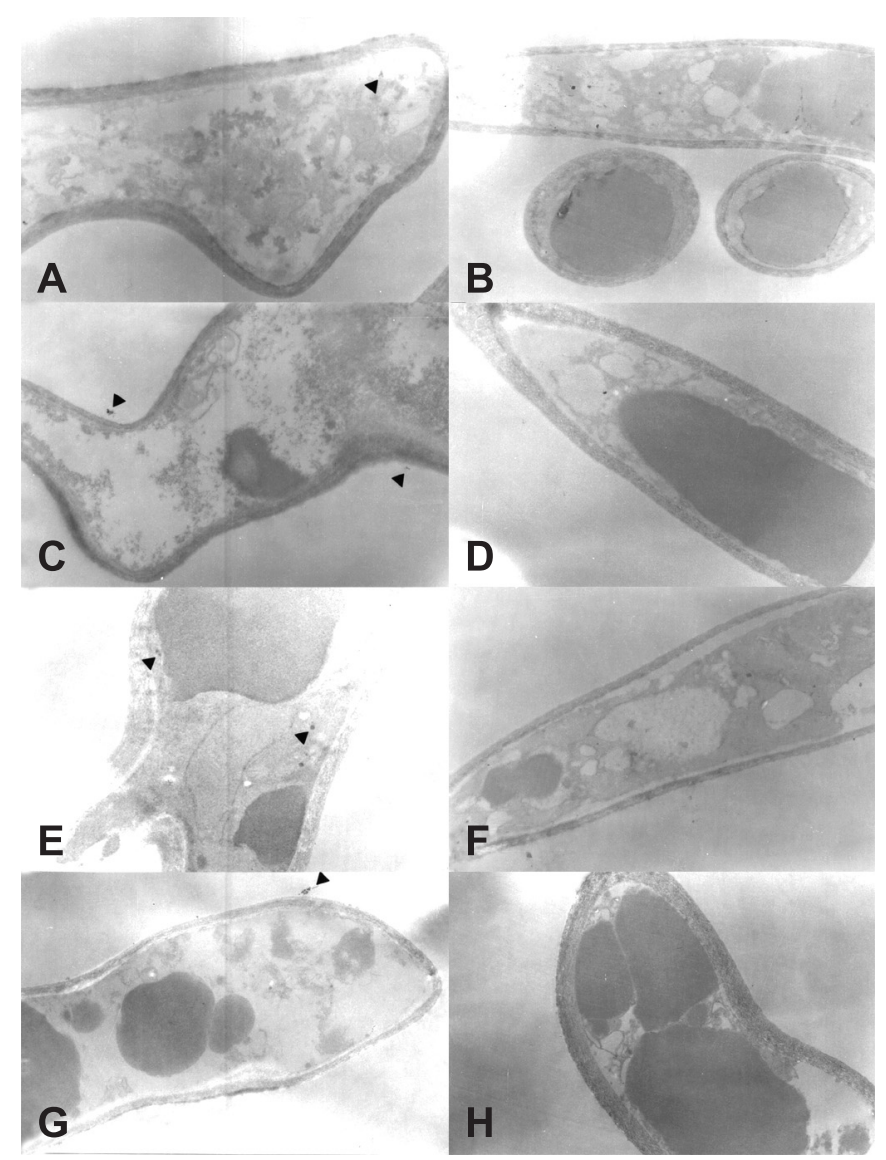

Figura 9. Cunninghamella elegans grown in SMM3 medium. Polyphosphate cytochemistry. A- 3 days 20000X; C- 6 days 27000X; E- 9 days 20000X; G-12 days 14000X. Reaction products ( ). B, D, F and $\mathrm{H}-$ control samples.

granules and vacuoles. The salt-soluble is possible located in the nucleus and the more highly polymerized polyP are localized at the cell surface $(65,72)$.

In this work the polyP content of fractions depended on the orthophosphate concentration in media and at different stages of growth. The polyP was assayed by the content of labile phosphorus in water-soluble, alkali-soluble and acid-insoluble fractions in samples collected at 6 and 12 days of cultive (points corresponding to the maximum and minimum total polyP content in mycelia). The results pointed out differences in the polyP content among the fractions studied.

Changes in fractions of alkali-soluble of polyP were significant during growth. The content of polyP in these fractions was larger at low initial Pi concentration in the culture medium. The content of polyP in this fractions was also higher than others fractions in both media and in different stages of growth.

Fungi are able to responde to an inumerous environmental alterations, such as gas concentrations, physical and chemical 
changes. A maximum growth of a fungi depends on its environment. Thus, physiological, biochemical, genetics and cytological studies are essential to determine the physical and nutritional conditions of a medium, which results in better growth rates and higher biomass production. A search for a medium composition, which stimulates a maximum growth is based on studies related to temperature, $\mathrm{pH}$, aeration, sources of carbon, nitrogen, phosphorus, in ideal concentrations $(1,2,25,26,27,46,53,67)$.

The use of ultrastructural research as a tool to better understand the fungal fine structure has expanded and contributed a great deal to the field of mycology. By means of electron microscopy it is possible to gain new insight into the organization and constitution of fungi cell wall at a level not revealed by the routine methods $(8,9,15,16,19,39,41,43,45,60)$.

The cytochemical staining of cellular polyP by lead salts permit the observation of polyP precipitated in situ with lead as metachromatic granules after exposure to the electron beam $(7,14,29,39,45)$.

The results presented in this work revealed the polyP location, structure and distribution in C. elegans grown in different orthophosphate concentrations. The present findings showed that C. elegans exhibited a cytochemical polyP labeling in different structures as well as different amounts according to the growth phase and orthophosphate content in the cultive medium. PolyP labeling was observed on cellular surface, cytoplasm and in intracellular structures such as vacuoles. Reaction products were observed in the form of electrondense granules and patches dispersed in the cytoplasm. The results obtained related to polyP location suggest the existence of poly $\mathrm{P}$ with differents functions according to its chain lenghts in $C$. elegans

Differences in localization, structure and content of polyP depends on the growth phase. This suggests that the polyP is developped in distinct phase of the growth cycle and is accumulated under certain growth conditions $(7,14,29,39,45,65,72)$.

PolyP located on the cell surface is related to the maintenance of the fine structural organization of cell wall was observed in bacteria, Neisseria gonorrheae, Propionibacterium acnes and Helicobacter pilori and yeasts, Neurospora crassa and Kluyveromyces marxianus $(7,14,29,39)$. On the other hand, the cytochemical localization of polyP in the yeast Saccharomyces cereviseae was observed outside of plasma membrane $(14,70)$.

In yeasts and bacteria vacuolar polyP correspond to a storage material and functions as biological cation exchanger $(14,29)$.

The results obtained in this work revealed an intense polyP labeling in cell cytoplasm of C. elegans.

In public and industrial waste water treatment plants the removal of both organic and inorganic compounds is essential in order to avoid a disturbance of the ecological balance of the rivers or seas in which the purified water is introduced. Especially the amount of phosphorous is limited to a threshold concentration. In contrast to the removal of nitrogenous compounds, for exemple, the elimination of phosphorous often requires the use of chemicals. A cheaper and environmentally more sociable method is the phosphorous removal by microorganisms. However, the identification of these organisms and the knowledge about their physiology is still fragmentary. Our observations provide further evidence of the polyP accumulation aspects in fungal physiology. Additional investigations are in progress to identify the exact role played by the increased rate of phosphate uptake and the accumulated intracellular polyP in the response of $C$. elegans to external orthophosphate concentration.

\section{ACKNOWLEDGEMENTS}

The authors are greateful to CNPq, PRONEX, PADCT and FINEP for the financial support.

\section{RESUMO}

\section{Efeitos do fósforo sobre a acumulação de polifosfato em Cunninghamella elegans}

O crescimento, consumo de fosfato e glicose, bem como o conteúdo de fósforo, a distribuição, estrutura e localização de polifosfato foram avaliados no micélio de Cunninghamella elegans cultivado em meios contendo diferentes concentrações de fosfato. Os resultados permitiram verificar a influência dessas concentrações de fosfato sobre o crescimento do fungo estudado. A maior concentração de fosfato proporcionou maior rendimento da biomassa ao longo do crescimento. Uma relação entre consumo de fosfato e glicose do meio foi observada em relação ao crescimento e a quantidade de polifosfato total nos micélios cultivados nos diferentes meios de cultivo. Distintos métodos de extração permitiram identificar e quantificar as diferentes frações do polifosfato celular de Cunninghamella elegans. A citoquímica ultrastrutural foi utilizada com sucesso para identificar a localização e a distribuição de polifosfato em Cunninghamella elegans. Os resultados revelaram diferenças no padrão de marcação citoquímica nas diferentes fases do crescimento e meios de cultivo. Uma marcação uniforme do polifosfato foi observada sobre a superfície celular, em especial, na parede celular e na membrana citoplasmática. Produtos de reação resultantes da marcação citoquímica foram também visualizados em estruturas trabeculares, vacuolares, vesiculares, sob a forma de corpos eletrondensos e grânulos dispersos no citoplasma. Os resultados demonstraram o potencial de Cunninghamella elegans na acumulação de polifosfato, sugerindo uma possível aplicação em processos biotecnológicos.

Palavras-chave: polifosfato, acumulação, citoquímica ultraestrutural, Cunninghamella elegans, ortofosfato. 


\section{REFERENCES}

1. Alexopoulos, C.J.; Mims, C.W.; Blackwell, M. Introductory Mycology. Jonh Wiley and Sons publishers, New York, 1996, 356p.

2. Aoki, J.; Nireuberg, H.I. Fusarium globosum from Subtropical Japan and the Effect of Different Light Conditions on its Conideogenesis. Mycoscience, 40:1-9, 1999.

3. Baijal, U., Mehrotra, B.S. The genus Cunninghamella - a reassessment. Sydowia, 33:1-13, 1980

4. Barak, Y.; Rijn, J.V. Relationship between Nitrite Reduction and Active Phosphate Uptake in the Phosphate-Accumulation Denitrifier Pseudomonas sp. Strain JR 12. Appl. Environm. Microbiol., 66:52365240, 2000.

5. Beever, R.E.; Burns, D.J.W. Adaptative changes in phosphate uptake by the fungus Neurospora crassa in response to phosphate supply. $J$. Bacteriol., 134:520-525, 1977.

6. Bolesch, D.G.; Keasling, J.D. Polyphosphate Binding and Chain Length Recognition of Escherichia coli Exopolyphosphatase. $J$. Biol. Chem., 275:33814- 33819, 2000.

7. Bode, G.; Mauch, F.; Ditschuneit, H.; Malfertheiner, P. Identification of structures containing polyphosphate in Helicobactr pilori. J. Gen. Microbiol., 139:3029-3033, 1993.

8. Bracker, C.E. The Ultrastructure and Development of Sporangia in Gilberteria persicaria. Mycologia, 60:1016-1067, 1968.

9. Campos Takaki, G.M.; Beakes, G.W.; Dietrich, S.M. Electron microscopy X-ray microprobe and cytochemical study of isolated cell walls of mucoralean fungi. Trans. British Mycol. Soc., 80:25-29, 1983.

10. Campos Takaki, G.M. Presence of inorganic polyphosphate in Mucoralean fungi. Annual Publisher of Research Center for Pathogenic Fungi and Microbial Toxicosis, 4:75-79, Chiba University, Japan, 2000.

11. De Souza, W. Técnicas básicas de microscopia eletrônica aplicadas às ciências biológicas. Sociedade Brasileira de Microscopia - Rio de Janeiro, 2000, 271p.

12. Dietrich, S.M.C. Presence of polyphosphate of low molecular weight in Zygomycetes. J. Bacteriol., 127:1408-1413, 1976.

13. Domsch, K.H.; Gams, W.; Anderson, T.H. Compendium of soil fungi. Academic Press, London, 1980, 120p.

14. Ebbel, J.P.; Colas, J.; Muller, S. II. Misu au Point de Méthodes de Détection Cytochimiques des Pollyphosphates. Exper. Cell Res., 15:28-36, 1958.

15. Edelmann, R.E.; Klomparens, K.L. Zygosporogenesis in Zygorhynchus heterogamus, with a proposal for standardization of structural nomenclature. Mycologia, 87:304-318, 1995a.

16. Edelmann, R.E.; Klomparens, K.L. Low temperature scanning electron microscopy of the ultrastructual development of zygospores and sporangiospores in Mycothypha africana, and the effects of cultural conditions on sexual versus asexual reprodution. Mycologia 90:212-218, 1995b

17. Foster, B.C.; Lister, D.L.; Zamecnik, J.; Coutts, R.T. The biotransformation of tranylcypromine by Cunninghamella equinulata. Can. J. Microbiol., 37:791-795, 1991.

18. Greenfield, N.J.; Hussain, M.; Lenard, J. Effects of growth state and amines on cytoplasmic and vacuolar $\mathrm{pH}$, phosphate levels in Saccharomyces cerevisea: a P-nuclear magnetic resonance study. Biochim. Biophys. Acta., 926:205-214, 1987.

19. Hawker, L.E.; Abbott, P.M. An electron microsope study of maturation and germination of sporangiospores of two species of Rhizopus. J. Gen. Microbiol., 32:295-298, 1963.

20. Henry, R.J.; Cannon, D.C.; Winkelman, J.W. Clinical chemistry, principles and techniques. Harper and Row, New York, 1974, 278p.

21. Hesseltine, C.W.; Anderson, R.F. Microbiological Production of Carotenóides I. Zygospore and Carotene producted by Intraspecific and crosses of Choanephoraceae in Liquid Media. Mycology, 49:449452,1957
22. Harold, F.M. Inorganic Polyphosphates in Biology: Structure, Metabolism, and Function. Bacteriol. Rev., 16:772-794, 1966.

23. Jennings, D.H. The Physiology of fungal nutrition. Cambridge University Press, England, 1995, 245p.

24. Johnson, M.; Carlson, M. Regulation of carbon and phosphate utilization. In: Jones, E.W.; Pringle, J.R.; Broach, J.R. (eds.). The molecular and cellular biology of the Saccharomyces gene expression. Cold Spring Harbor, New York, 1992, p.295.

25. Kana-Uchi, A.; Fukatsu, T. Light Induced Fruit Body Formation of an Entomogenous Fungus Paecilomyces termipes. Mycoscience, 40:349-351, 1999

26. Kihara, J.; Watanabe, Y.; Honda, Y. Suppression and Reactivation of UV-Induced Sporulation by Blue Light in Bipolaris oryzae. Mycoscience, 40:363-366, 1999.

27. Kitamoto, Y.; Akita, K.; Horikoshi, T. Effects of High-Temperature Treatment on Two Essential Light Processes and na Intervening Dark Process in Photoinduced Pileus Primordium Formation of a Basidiomycete, Favolus arcularius. Mycoscience, 40:103-108, 1999.

28. Kornberg, A. Inorganic polyphosphate: toward making a forgotten polymer unforgettable. J. Bacteriol., 177:491-496, 1995.

29. Kjeldstad, B.; Heldal, M.; Nissen, H.; Bergan, A.S.; Eujen, K. Changes in polyphosphate composition and localization in Propionibacterium acnes after near-UV irradiation. Can. J. Microbiol., 37:562-567, 1991.

30. Kuroda, A.; Ohtake, H. Molecular Analysis of Polyphosphate Accumulation in Bacteria. Biochemistry Mosc., 65:304-308, 2000.

31. Kulaev, I.S.; Vagabov, V.M.; Kulakovskaya, T.V.; Lichko, L.P.; Andreeva, N.A.; Trilisenko, L.V. The development of A.N. Belozersky's Ideas in Polyphosphate Biochemistry. Biochemistry Mosc., 65:271-278, 2000.

32. Kulaev, I.S. Biochemistry and Biotechnology of Inorganic Polyphosphates. Biochemistry Mosc., 65:269-270, 2000

33. Keasling, L.D.; Van Dien, S.J.; Trelstad, P.; Renninger, N.; Mcmahon, $\mathrm{K}$. Application of polyphosphate metabolism to environmental and biotechnological problems. Biochemistry Mosc., 65:324-331, 2000.

34. Kulaev, I.; Kulakovskaya, T. Polyphosphate and Phosphate Pump. Ann. Rev. Microbiol., 54:709-734, 2000.

35. Kuroda, A.; Kornberg, A. Polyphosphate Kinase as a Nucleoside Diphosphate Kinase in Escherichia coli and Pseudomonas aeruginosa. Proc. Nat. Acad. Sc., 94:439-442, 1997.

36. Kumble, K.D.; Kornberg, A. Endopolyphosphatases for Long Chain Inorganic Polyphosphate in Yeast and Mammals. J. Biol. Chem., 271:27146-27151, 1996.

37. Kumble, K.D.; Kornberg, A. Inorganic Polyphosphate in Mammalian Cell and Tissues. J. Biol. Chem., 270:5818-5822, 1995.

38. Kornberg, A.; Rao, N.N.; Ault-Riche, D. Inorganic Polyphosphate: A Molecule of Many Functions. Ann. Rev. Biochem., 68:89-125, 1999.

39. Klomparens, K.L. The development and application of ultrastructural research in mycology. Mycopathologia, 109:139-148, 1990.

40. Lamacka, M.; Sajbidor, J. The content of prostaglandins and their precursors in Mortierella and Cunninghamella species. Lett. Appl. Microbiol., 26:224-226, 1998.

41. Mckeown, T.A.; Moss, S.T.; Jones B.G. Ultrastructure of Ascospores of Tunicaspora australiensis. Mycol. Res., 100:1247-1255, 1996.

42. Mcgrath, J.W.; Quinn, J.P. Intracellular Accumulation of Polyphosphate by the Candida humicola G-1 in Response to Acid pH. Appl. Environm. Microbiol., 66:4068-4073, 2000.

43. Maia, L.C.; Kimbrough, J.W.; Benny, G. Ultrastructural studies of the spore wall of Gigaspora Albida (Glomales). Mycologia, 85:883889,1993

44. Mino, T.; Vanloosdrecht, M.C.M.; Heijnen, J.J. Microbiology and Biochemistry of The enhanced Biological Phosphate Removal Process. Wat. Res., 32:3193-3207, 1998. 
45. Mims, C.W. Using electron microscopy to study plant pathogenic fungi. Mycologia, 83:1-19, 1991.

45. O'Donnel, K.L. Zygomycetes in culture. University of Georgia. 1979, $257 \mathrm{p}$.

46. Oshima, Y. The phosphatase system in Saccharomyces cerevisiae. Genes Gen. Systems, 72:323-334, 1997.

47. Orlowski, I.M. Mucor dimorphism. Microbiol. Rev., 55:234-258, 1991.

48. Poolman, B.; Nijssen, R.M.J.; Konnings, W.N. Dependence on Streptococcus lactis phosphate transport on internal phosphate concentration and internal pH. J. Bacteriol., 169:5373-5378, 1987.

49. Pothuluri, J.V.; Freeman, J.P.; Evans, F.E.; Cerniglia, C.E. Fungal metabolism of acenaphthene by Cunninghamella elegans. Appl. Environm. Microbiol., 58:3654-3659, 1992.

50. Pothuluri, J.V.; Doerge, D.R.; Churchwell, M.I.; Fu, P.P.; Cerniglia, C.E. Fungal metabolism of nitrofluoranthenes. J. Toxicol. Environm. Health., 53:153-174, 1998.

51. Pothuluri, J.V.; Sutherland, J.B.; Freeman, J.P.; Cerniglia, C.E. Fungal biotransformation of 6-nitrochrysene. Appl. Environm. Microbiol., 64:3106-3109, 1998.

52. Rivero, F.; Cerdá-Olmedo, E. Spore Germination in Phycomyces blakesleeanus. Mycologia, 86:781-786, 1994.

53. Rashid, M.H.; Rumbaugh, K.; Passador, L.; Davis, D.G.; Hamood, A.N.; Iglewski, B.H.; Kornberg, A. Polyphosphate Kinase is Essencial for Biofilm Development, Quorum sensing, and Virulence of Pseudomonas aeruginosa. Proc. Nat. Acad. Sc. USA., 97:96369641,2000

54. Rashid, M.H.; Kornberg, A. Inorganic Polyphosphate is Needed for Swimming, Swarming, and Twitching Motilities of Pseudomonas aeruginosa. Proc. Nat. Acad. Sc., USA., 97:4885-4890, 2000a.

55. Rashid, M.H.; Kornberg, A. Inorganic Polyphosphate is Required for Motility of Bacterial Pathogens. J. Bacteriol., 182:225-227, 2000b.

56. Rao, N.N.; Liu, S.; Kornberg, A. Inorganic Polyphosphate in Escherichia coli: The Phosphate Regulon and the Stringent Response. J. Bacteriol., 180:2186-2193, 1998.

57. Rao, N.N.; Kornberg, A. Inorganic Polyphosphate Supports Resistance and Survival of Stationary-Phase Escherichia coli. J. Bacteriol., 178:1394-1400, 1996.

58. Reddy, C.S.; Acosta, D.; Davis, P.J. Microbial models of mammalian metabolism: biotransformations of phenacetin and its O-alkyl homologues with Cunninghamella species. Xenobiotica, 20:12811297,1990

59. Saikawa, M.; Katsurashima, E. Light and electron microscopy of a new species of Euryancale Producing Phallus-Shaped Conidia. Mycologia, 85:24-29, 1993.

60. Shiba, T.; Tsutsumi, K.; Ishige, K.; Noguchi, T. Inorganic Polyphosphate and Polyphosphate Kinase: Their novel Biological Functions and Applications. Biochemistry Mosc., 65:315-323, 2000 .
61. Shipton, W.A.; Lunn, J.A. Sporangiole morphology and species saparation in Cunninghamella. Trans. British Mycol. Soc., 74:483$491,1980$.

62. Shari'a, A.E.N.; Nascimento, A.E.; Lima, M.A.B.; Takaki, G.M.C.; De Souza, W. Polyphosphate in Zygomycetes: A cytochemical study. Braz. J. Microbiol., 33:119-126, 2002.

63. Smith, J.E.; Deans, S.G.; Anderson, J.G.; Davis, B. The Nature of Fungal Sporulation. In: Biotechnology and Fungal Differentiation. Fems Symposium, 40:17-41, 1977.

64. Smirnov, A.V.; Kulakovskaya, I.S.; Kulaev, I.S. Phosphate accumulation by an extremely halophilic archae Halobacterium salinarium. Process Biochem., 37:643-649, 2002.

65. Schwartz, H.; Liebig Weber, A.; Hochstatter, H.; Bottcher, H. Microbial oxidation of ebastine. Appl. Environm. Microbiol., 44:731735, 1996.

66. Tham, L.X.; Matsuhashi, S.; Kume, T. Growth and Fruit Body Formation of Gracioderma lucidum on Media Supplemented with Vanadium, Selenium and Germanium. Mycoscience, 40:87-92, 1999.

67. Trufem, S.F.B. Mucorales do estado de São Paulo: 3. Gêneros Circinella van Tieghem and Le Monier e Cunninghamella Matruchot. Rickia, 9:113-120, 1981

68. Tzeng, C.M.; Kornberg, A. The Multiple Activities of Polyphosphate Kinase of Escherichia coli and their Subunit Structure Determined by Radiation Target Analysis. J. Biol. Chem., 275:3977-3983, 2000.

69. Urech, K.; Durr, M.; Boller, I.H.; Wieken, A.; Schwencke, J. Localization of polyphosphate in vacuoles of Saccharomyces cerevisiae. Arch. Microbiol., 116:275-278, 1978.

70. Van Loosdrecht, M.C.; Smolders G.J.; Kuba, T.; Heijnen, J.J. Metabolism of Microorganisms Responsible for Enhanced Biological Phosphorus Removal from Wastewater. Antonie Van Leeuwenhoek, 71:109-116, 1997

71. Vagabov, V.M.; Trilisenko, L.V.; Kulaev, I.S. Dependence of Inorganic Polyphosphate Chain Length on the Orthophosphate Content in the Culture Medium of the Yeast Saccharomyces cerevisiae. Biochemistry, 65:349-354, 2000.

72. Weitzman, I.; Whittier, S.; Mckitrick, J.C.; Della-Latta, P. Zygospore: the last word in identification of rare and atypycal zygomycetes isolated from animal specimens. J. Clin. Microbiol., 33:781-783, 1995.

73. Wood, H.G.; Clarck, J.E. Biological Aspects of Inorganic Polyphosphate. Ann. Rev. Biochem., 57:253-260, 1988.

74. Zhang, D.; Hansen Jr., Eb.; Deck, J.; Heinze, T.M.; Sutherland, J.B.; Cerniglia, C.E. Fungal biotransformation of the antihistamine azatadine by Cunninghamella elegans. Appl. Environm. Microbiol., 62:3477-3479, 1996.

75. Zhang, D.; Freeman, J.P.; Sutherland, J.B.; Walker, A.E.; Yang, Y.; Cerniglia, C.E. Biotransformation of chlorpromazine and methdilazine by Cunninghamella elegans. Appl. Environm. Microbiol., 62:798803, 1996. 